\title{
PAISAGENS LITORÂNEAS URBANAS: novas perspectivas de análise
}

\author{
Coastal Urban Landscapes: new perspectives of analysis
}

André Nunes de Sousa*

\section{Resumo}

O presente artigo trata das possibilidades de compreensão dos significados atribuídos às paisagens litorâneas da orla atlântica de Salvador - BA, Brasil, a partir de uma aproximação fenomenológica dos anseios subjetivos dos sujeitos que apreendem tais paisagens. Tomando como base as leituras de dois filósofos precursores da fenomenologia - Jean-Paul Sartre e Gaston Bachelard, foi esboçada uma metodologia a fim de enriquecer a compreensão das dinâmicas das cidades contemporâneas. As teorias desenvolvidas por esses dois autores sobre a imagem e sobre a imaginação abrem novas perspectivas de análise sobre o estudo das paisagens e das imagens de paisagem. Por fim, o artigo versa sobre outras leituras possíveis para as paisagens, diferentes dos discursos hegemonicamente por elas veiculados.

Palavras-chave: Litoral, paisagem, fenomenologia.

\begin{abstract}
This cientific article discusses about possibilities to understanding the meanings attributed to coastal landscapes in Salvador's Atlantic coast - Bahia, Brazil - using a phenomenological approach about subjective and individuals wishes of person who feeling this landscapes. The proposed methodology is based on JeanPaul Sartre and Gaston Bachelard, who were the precursos of phenomenological philosophers, to improve and diversify knowlodge about the dynamic of contemporary cities. The theories developed by the refered authors, about image and imagination, increase new analysis perspectives above study of landscapes and landscape image. Even the last, this cientific article discusses about other possibles to realise the landscapes, everyone is different from the hegemonic discourses which they, in general, is affiliated.
\end{abstract}

Key words:Coast, landscap, phenomenology.

\section{Resumen}

Este artículo discute las posibilidades de comprensión de los significados atribuidos a los paisajes de la costa atlántica de Salvador - Bahía, Brasil, desde un enfoque fenomenológico de los deseos subjetivos de los individuos que nota esos paisajes. Con base en las lecturas de dos precursores de la fenomenología Jean-Paul Sartre y Gaston Bachelard, se diseñó una metodología con el fin de enriquecer la comprensión de la dinámica de las ciudades contemporáneas. Las teorías desarrolladas por estos dos autores sobre la imagen y la imaginación abren nuevas perspectivas de análisis del estudio de los paisajes y las imágenes de paisaje. Por último, el artículo plantea otras lecturas posibles de los paisajes, a diferencia de los discursos hegemónicos que se sirve.

Palabras clave: Costa, paisaje, fenomenología

(*) Msc. pela Universidade Federal da Bahia - Rua Nilson Costa, 494, Ap.101, CEP 40.270550, Vila Laura, Salvador (BA), Brasil, Tel: (+55 71) 96025287 - andrends@yahoo.com.br 


\section{INTRODUÇÃO}

No presente artigo defendo a ideia de que a aproximação fenomenológica dos anseios subjetivos dos que constroem e apreendem as paisagens de nossas cidades pode enriquecer, em muito, a compreensão da cidade contemporânea. Para tanto, ensaiei algumas experimentações metodológicas apoiadas em autores que nos ensinam sobre as relações entre a consciência e os fenômenos do mundo. Falo, especialmente, das contribuições da fenomenologia da imaginação escrita por Gaston Bachelard e da fenomenologia do Ser desenvolvida por Jean-Paul Sartre.

Para as análises que desenvolvo, tomei como objeto de estudo paisagens de trechos da orla oceânica de Salvador, pelo fato de os espaços litorâneos terem se transformado nas últimas décadas em áreas de grande interesse social (DANTAS, 2009).

O primeiro autor que faço referência é Jean-Paul Sartre. Sartre (2008), numa obra introdutória intitulada A Imaginação, demonstra um interesse fascinante pelas "novidades" que os estudos fenomenológicos inauguravam na filosofia. Neste livro, Sartre traça observações decisivas sobre a consciência, a coisa e a imagem da coisa, o que marca uma ruptura radical com o idealismo (ao negar que a coisa seja constituinte da consciência) e nos oferece pistas preciosas sobre as formas como elaboramos a realidade.

Mostrando-se encantado com as leituras de Edmund Husserl, Sartre (2008) caminha a passos largos para uma elaboração teórica que lhe fará distinguir a consciência daquilo que se tem consciência, sendo a imagem uma expressão das elaborações psíquicas que a consciência faz da coisa.

A concepção de intencionalidade é chamada a renovar a noção de imagem. Sabemos que, para Husserl, todo estado de consciência, ou melhor - como dizem os alemães e como diremos com eles - toda consciência é consciência de alguma coisa. (...) na medida em que elas são consciência de alguma coisa, dizemos que elas se relacionam intencionalmente a essa coisa (2008, p.120).

Nessas breves palavras há uma questão-chave a ser desdobrada e que se mostra importante para o estudo fenomenológico das paisagens. Ao se relacionar intencionalmente com as coisas, surge de imediato para a consciência uma diferença entre percepção e ficção no seu processo de criação das imagens: a percepção, dirá Sartre, está intrinsecamente ligada a um objeto sensível externo a nós, enquanto que a ficção não está "presa" a uma realidade material a qual apreendemos com nosso sistema sensitivo. Para Sartre, a ficção seria síntese ativa, um produto de nossa espontaneidade ao passo que a percepção seria uma síntese passiva.

O segundo autor precursor da fenomenologia que auxiliou no aprofundamento dessas análises foi Gaston Bachelard. Ao desenvolver a fenomenologia da imaginação, Bachelard $(1998 ; 2002)$ nos fala do caráter vanguardista do ato de imaginar; a força que esse ato tem de criar outras realidades. Construindo uma crítica próxima à de Sartre, Bachelard rompe com a tradição filosófica que admitia uma postura passiva da consciência perante as coisas do mundo. A imaginação aparece em sua obra como possibilidade de subversão.

Trabalhando com as imagens poéticas - aquelas que guardam relações com arquétipos adormecidos no inconsciente das pessoas - Bachelard (1998) busca a transubjetividade que acredita haver nestas imagens. Algo capaz de sensibilizar as múltiplas subjetividades que as apreendem. Em verdade, o que o autor busca é medir a força, a amplitude e o sentido desta transubjetividade.

As relações entre as imagens poéticas e a diversidade de consciências para as quais estas imagens se apresentam têm, para Bachelard, um caráter iminentemente dialético. Estas relações se transformam a todo instante: "Toda esta subjetividade, transubjetividade, não podem ser determinadas definitivamente. A imagem poética é, com efeito, essencialmente variacional" (BACHELARD, 1998, p. 03).

Trabalhar com paisagens litorâneas significou assim estar diante de imagens poéticas a quase todo instante, diante de imagens transubjetivas, de imagens com o poder de atrair distintas subje- 
tividades, de seduzir e de fazer sonhar o rico e o pobre, os habitantes locais e os forasteiros, os de credo e os descrentes, etc.

\section{O DEVANEIO DA MATÉRIA}

Bachelard (2002), ao falar da relação dialética entre a consciência e a imagem poética, rompe com algumas tradições filosóficas, dentre as quais, a predominância do interesse dos estetas pelas formas.

Já Duarte (2003), nos conta um pouco do longo caminho trilhado por aqueles que se ocuparam do estudo da arte e do belo, desde o classicismo, passando pelo romantismo, até a elaboração das chamadas teorias psicológicas, dominadas pela gestalt.

Segundo Duarte (2003), a palavra gestalt, que se traduz ao idioma português como forma, figura ou mesmo contorno, resumiria a ideia central da teoria, desenvolvida pelo psicólogo alemão Wertheimer, que atribui a sensação de beleza, ou experiência estética, à inteligibilidade das formas.

Ao apreender as formas cognitivamente, o indivíduo seria remetido a uma sensação de prazer por estar elaborando um pouco mais do mundo. A intencionalidade seria intrínseca a esse processo. A consciência lança-se, mediada por nosso sistema sensitivo, na direção do objeto observado, a fim de "ajudá-lo" a nos oferecer "sua" beleza.

Bachelard (2002), no entanto, não nega a dimensão ou importância da forma na criação das imagens poéticas. O que o filosofo tenta é elucidar que, tão importante quanto a forma, é a matéria que essa forma ornamenta. A matéria, que é adornada pela forma, tem, para Bachelard (2002), um poder imensurável de sedução tal e qual essa forma.

Quando começamos a meditar sobre a noção de beleza da matéria, ficamos imediatamente impressionados com a carência da causa material na filosofia estética. Pareceu-nos, em particular, que se subestimava o poder individualizante da matéria. Por quê se associa sempre a noção de indivíduo à de forma? Não haverá uma individualidade em profundidade que faz com que a matéria seja, em suas menores parcelas, sempre uma totalidade? (BACHELARD, 2002, p.03).

A relação, estudada por Bachelard, entre a intenção imaginante e os elementos terra, fogo, água e ar, se constitui em um dos pilares da teoria robusta desenvolvida pelo filósofo, sobre a relação dialética entre a consciência e a matéria, relação criadora das imagens poéticas .

Bachelard (2002, p.05) busca compreender o devaneio da matéria e sua importância na constituição das imagens poéticas, pois, para ele, "Sonha-se antes de contemplar. Antes de ser um espetáculo consciente, toda paisagem é uma experiência onírica. Só olhamos com paixão estética as paisagens que vimos antes em sonho".

As aproximações e diferenças entre Bachelard e Sartre são percebidas a cada página lida. Os primeiros ensaios de Sartre (2008) sobre a imaginação encontram eco nos escritos de Bachelard (2002, p. 01):

As forças imaginantes de nossa mente desenvolvem-se em duas linhas bastante diferentes.

Umas encontram seu impulso na novidade, divertem-se com o pitoresco (...) as outras forças imaginantes escavam o fundo do ser, querem encontrar no fundo do ser, ao mesmo tempo, o primitivo e o eterno. Expressando-nos filosoficamente desde já, poderíamos distinguir duas imaginações: uma imaginação que dá vida a causa formal e uma imaginação que dá vida a causa material, ou, mais brevemente, a imaginação formal e a imaginação material.

Se há divergências de método, no que se refere à apreensão da essência dos fenômenos, entre Sartre (2005) e Bachelard (1998), estes convergem, mais uma vez, quando Sartre (2005) discorre sobre a consciência como sendo consciência posicional no mundo. 
Para uma melhor análise da base teórico-metodológica aqui apresentada e seus potenciais no estudo das paisagens litorâneas de nossas cidades e seus elementos constituintes, será demonstrado de agora em diante um conjunto de entrevistas que realizei com algumas pessoas que concordaram em ajudar nessa tarefa de aproximação dos anseios subjetivos dos que apreendem as paisagens litorâneas de nossas cidades. Serão apresentados os resultados dos ensaios metodológicos propostos referentes às indicações de Bachelard $(1998,2002)$ sobre a adesão do sujeito às imagens poéticas.

\section{O EXERCÍCIO DO “NÃO-SABER”}

Ao desenvolver a fenomenologia da imaginação, Bachelard (1998) nos ofereceu métodos que convidam o leitor a experimentar novas formas de apreensão do fenômeno das imagens poéticas. Bachelard (1998) propõe a apreensão do "aqui e agora" da imagem poética, tomando a imagem de modo isolado e pautando-nos no "não-saber". Isto é, que nos coloquemos diante das imagens poéticas, aquelas capazes de seduzir distintas subjetividades, nos despindo da bagagem de informação que trouxemos sobre elas, para sentirmos as sensações que essas imagens evocam.

$\mathrm{Na}$ apresentação do fenômeno das paisagens litorâneas (tomadas aqui como imagens poéticas) a diferentes consciências, busquei avaliar as sensações que essas imagens evocavam em mim e nos entrevistados. Esbocei alguns procedimentos.

De início, pedi aos entrevistados que relatassem um pouco de suas experiências com o mar. Buscava, tão somente, uma maior aproximação com os entrevistados, tentava conhecê-los um pouco mais. Em seguida, experimentei o exercício de adesão às imagens poéticas pautando-o num esforço de desprendimento de nossas (as minhas e as dos entrevistados) experiências em relação a essa porção da cidade, colocando a história "em suspensão". Neguei, o quanto pude, ideias apriorísticas que influenciassem na escolha dos que colaboraram com a pesquisa. Defini, apenas, a maior diversidade possível de situações espaciais.

Nos parágrafos que se seguem demonstro mais detalhadamente como realizei o exercício ao passo que apresento as contribuições daqueles que, dentre os entrevistados, ofereceram maiores possibilidades de discussão do método, isto é, seus avanços, suas restrições, necessidades de ajustes, etc.

Percorria a orla oceânica de Salvador quando decidi que a praia que fica diante de uma área de urbanização precária, conhecida como Vila Matos, no bairro do Rio Vermelho, se constituía num bom lugar para a efetivação do exercício, uma vez que esta localidade destoa de seu entorno de infraestrutura relativamente boa. Foi nesse trecho de orla que encontrei a Sra. M. L, 38 anos, promotora de vendas.

Eram quase $09 \mathrm{~h}$ da manhã de um dia de meio de semana. Dava para contar nos dedos das mãos as pessoas que avistei na praia. A rua estava pouco movimentada. Sentei num banco de cimento próximo a uma das escadas de acesso à praia e fitei o mar e seu entorno por alguns minutos. Difícil traduzir as sensações, mas era algo como se o tempo tivesse parado, como se eu tivesse tempo de sobra para fazer nada. O mar, a temperatura amena da manhã e o pouco movimento da paisagem pareciam deixar o tempo mais vagaroso. Segui em direção a Sra. M. L. e me apresentei.

A entrevistada nasceu em Salvador e mora no bairro de Rio Vermelho. O lazer ligado à praia sempre esteve presente em sua vida. Ela lembra de um afogamento que sofreu quando era mais jovem, o que lhe fez carregar, daí por diante, um certo receio de entrar no mar, ao menos nas águas mais fundas ou agitadas.

A Sra. M. L. ainda fez questão de nos falar de sua crença: é evangélica e com um sorriso sereno disse que "o mar quem fez foi Jesus. O mar é a presença de Deus. Tenho orado muito nas minhas caminhadas, isso aqui traz calma para a gente".

Pedi então que ela experimentasse o exercício que Bachelard (1998) propõe para apreensão das imagens poéticas, o exercício do não-saber. Convidei-a pra deixar sua história com o mar um pouco de lado, e lhe solicitei que relatasse um pouco das sensações que a paisagem lhe trazia naquele exato momento. 
A entrevistada voltou-se para o mar parecendo esquecer o entorno. Ouvi da Sra. M. L. palavras que iniciam a discussão que pretendo desenvolver nesse tópico:

(o mar) É uma coisa muito fantástica a imensidão dele. Eu penso no meu Deus que fez o mar, não é? Ele é grande, é enorme. Eu fico olhando assim... meu Deus! Lá mais para o fundo, mais além... É o encontro com Deus. O mar e o céu assim, a gente acha que estão ligados. A gente sabe que não é assim, mas quando a gente olha parece que estão ligados.

Quando optei por experimentar o método do "não-saber" com outras pessoas tentava, sobretudo, fugir de um saber apriorístico sobre a teoria que queria avaliar; tentava validá-lo segundo as palavras que diziam outras consciências para as quais as imagens poéticas se apresentam.

Se podemos pensar as palavras da Sra. M. L. como reveladoras de uma apreensão das imagens poéticas condicionada por sua crença, formada ao longo de sua história de vida, podemos, também, pensar que essa experiência estética, que ela vive em suas caminhadas matinais, e que a manifesta por essa referência mística, é só mais uma forma de comunicar um contentamento que é mais íntimo, difícil de expressar por palavras. Aquele contentamento que se manifestou antes no primeiro sorriso, quando ela se virou inicialmente para o mar, do que nas palavras que articulou posteriormente.

Para refletirmos melhor sobre essas questões e para confirmamos tais pressupostos, serão analisados outros relatos que nos darão mais possibilidades de avaliação do método proposto para o estudo das paisagens.

Segui para outra situação espacial. Foi no coqueiral do trecho da orla marítima, conhecido como Chega-Nego, situado no bairro do Costa Azul, que encontrei o Sr. R. S., 39 anos, morador do bairro da Pituba em Salvador, realizando suas atividades físicas junto a equipamentos de ginástica em frente ao mar. O sol, àquela hora do dia, estava quente e o mar realçava-se por um azul retinto.

Pedi ao Sr. R. S. que contasse um pouco de suas experiências com o mar, e ele falou:

Desde pequeno minha mãe me trazia para a praia, apesar de eu não gostar muito. Não gosto muito do sol, mas tenho que vir para olhar a praia, para caminhar, olhar o mar para mim é uma terapia. Eu venho para conversar com o mar, com a natureza. É bom, mas ele lá e eu cá. Eu quero distância. Eu gosto, mas é só para olhar. Eu tenho muito medo apesar de saber nadar. Nunca me afoguei, mas não gosto muito nem do sol nem de ficar dentro d'água. Então é aqui que venho e que conto todos os meus problemas para mim mesmo, mas parece que o mar escuta, que às vezes até responde com algum gesto, sei lá. Alguns toques. Eu não sei, talvez seja algo meio esotérico e tal... é inexplicável.

O Sr. R. S. morou durante a infância no bairro de Plataforma, localizado no Subúrbio Ferroviário de Salvador.

Eu morava em Plataforma, na Suburbana, mas eu não ia a praia de lá, eu não gostava. Eu vinha para a de cá. Eu não gostava do público que frequentava a praia de lá. Lá é tudo largado, a praia é suja. Aqui o pessoal limpa às segundas-feiras, afinal é a parte nobre. Lá é muito pior.

Pedi então a ele que olhasse a paisagem sob o ângulo que quisesse e relatasse as sensações que essa paisagem lhe trazia naquele momento. Voltado para o mar ele o Sr. R. S. disse: "felicidade", e, virando-se para o lado da rua, falou, "eu vejo progresso, os prédios aparecendo, subindo".

Quando o Sr. R. S. falou das praias, sobretudo as da sua infância, fazia uma distinção nítida no valor (de uso) que atribuía às duas orlas da cidade. Enquanto as "praias de lá", isto é, as da orla da Baía de Todos os Santos, eram negadas pelo entrevistado, a orla atlântica lhe remetia a um estado de felicidade.

Não avançaremos por pólos opostos. A ideia não é negar as experiências que, dotadas de valor, direcionam nossas preferências na vida. Pretendo, antes, pensar no campo de tensão entre as determinações objetivas e as indeterminações da subjetividade (SARTRE, 2005). 
Se colocamos a história "em suspensão" é para num momento seguinte voltarmos ao fluxo histórico. O que está em jogo é a capacidade maior ou menor que cada entrevistado demonstra em se colocar diante da imagem no momento da imagem. Trabalhando com outras consciências, sempre haverá a dúvida de quanto avançamos nas proposições de Bachelard.

Outra rica contribuição foi dada pela Sra. J. A., 45 anos, massoterapeuta, que nos olhava bem de longe enquanto eu entrevistava o Sr. R. S. por entre aqueles coqueiros. Neste grande coqueiral estão dispostas várias macas ou cadeiras especializadas nas quais um número significativo de massoterapeutas presta seus serviços. Vendo aquela senhora com ar de curiosidade decidi caminhar ao seu encontro para me apresentar e testar o método de aproximação fenomenológica.

A nova entrevistada afirmou ter nascido no bairro do Rio Vermelho, onde passou toda sua juventude e, na atualidade, morar no bairro da Boca do Rio.

Relatando sua experiência com o mar ela disse:

O mar tem um poder muito grande de me tranquilizar, sabe? Ele me acalma. Quando eu era adolescente eu era assim meio agitada, e eu tinha uma coisa assim que me chamava e eu ia para o mar. Eu sentava nas pedras lá do Rio Vermelho, no Buracão. Eu ia para lá, ficava olhando para o mar e eu me acalmava. Era como se fosse uma higiene mental, e até hoje eu sou assim. Quando eu não tenho nada para fazer eu fico aqui olhando para o mar, às vezes a gente vê até baleias, os peixinhos pulando, as gaivotas dando voltas, circulando aonde tem peixe.

Com uma voz mansa e respiração lenta, a Sra. J. A. continuou a falar quando lhe propus fixar a paisagem e relatar suas sensações.

Eu sinto felicidade, energia e paz. Agora, se eu me virar para trás (para a rua) tenho a sensação de stress, os carros em alta velocidade. Parece que vão voar para cá, dá medo. Agora, olhando para cá (o mar) eu sinto paz. Engraçado, não é? É aqui pertinho, mas eu consigo ficar em paz. Aqui eu consigo até ouvir os pássaros cantando, às vezes eles brigam (risos). Eu nem percebo o barulho do trânsito. É só no barulhinho do mar e no cliente que eu fico focada. É incrível... é na beira de uma pista e você se desliga total. É incrível. Mas não sou só eu não. A gente conversa aqui entre os colegas e a sensação é a mesma. Você escuta só o barulho do mar, do vento, e você não escuta mais o barulho dos carros.

Ouvindo a Sra. J. A., tive a impressão de que ela falava da mesma transubjetividade da qual discorre Bachelard nos seus textos - a experiência que a massoterapeuta compartilha com seus colegas de profissão que se "desligam" do entorno agitado e se deixam seduzir pela imagem poética do mar, seus movimentos, suas cores, seus sons e cheiros. A adesão a imagem poética, transsubjetiva, aparece mais nítida com essa entrevistada. Sua voz mansa, seu jeito de se referir ao mar, denunciava maior entrega aos espaços amados (BACHELARD, 1998).

Realizando esse exercício, deparei-me com inusitadas formas de apropriação da orla marítima. Foi curioso notar que um expressivo número de pessoas ocupa pequeníssimos "enclaves" de praia, formados pelos movimentos epirogenéticos que delinearam o acidentado relevo de Salvador, em tempos geológicos remotos, e recortaram sensivelmente boa parte da costa da cidade, conforme se pode verificar na figura 1 .

A primeira impressão foi a de estar diante de pessoas "espremidas" por um modelo de orla excludente, que se não é tão opressor pela arquitetura das formas, o é pelas barreiras simbólicas que são levantadas pelas territorialidades dos diferentes grupos/classes sociais. Contudo, as palavras que ouvi dessas pessoas trouxeram a sensação de sentido de obra (LEFEBVRE, 2006) para a cidade.

Foi num dia ensolarado, em um dos períodos diários de recuo da maré, que avistei um senhor sentado com algumas crianças nos afloramentos rochosos entre as praias do Porto e do farol da Barra. $\mathrm{O}$ grupo se espalhava por pequenas poças que se formam nos momentos de maré baixa. 


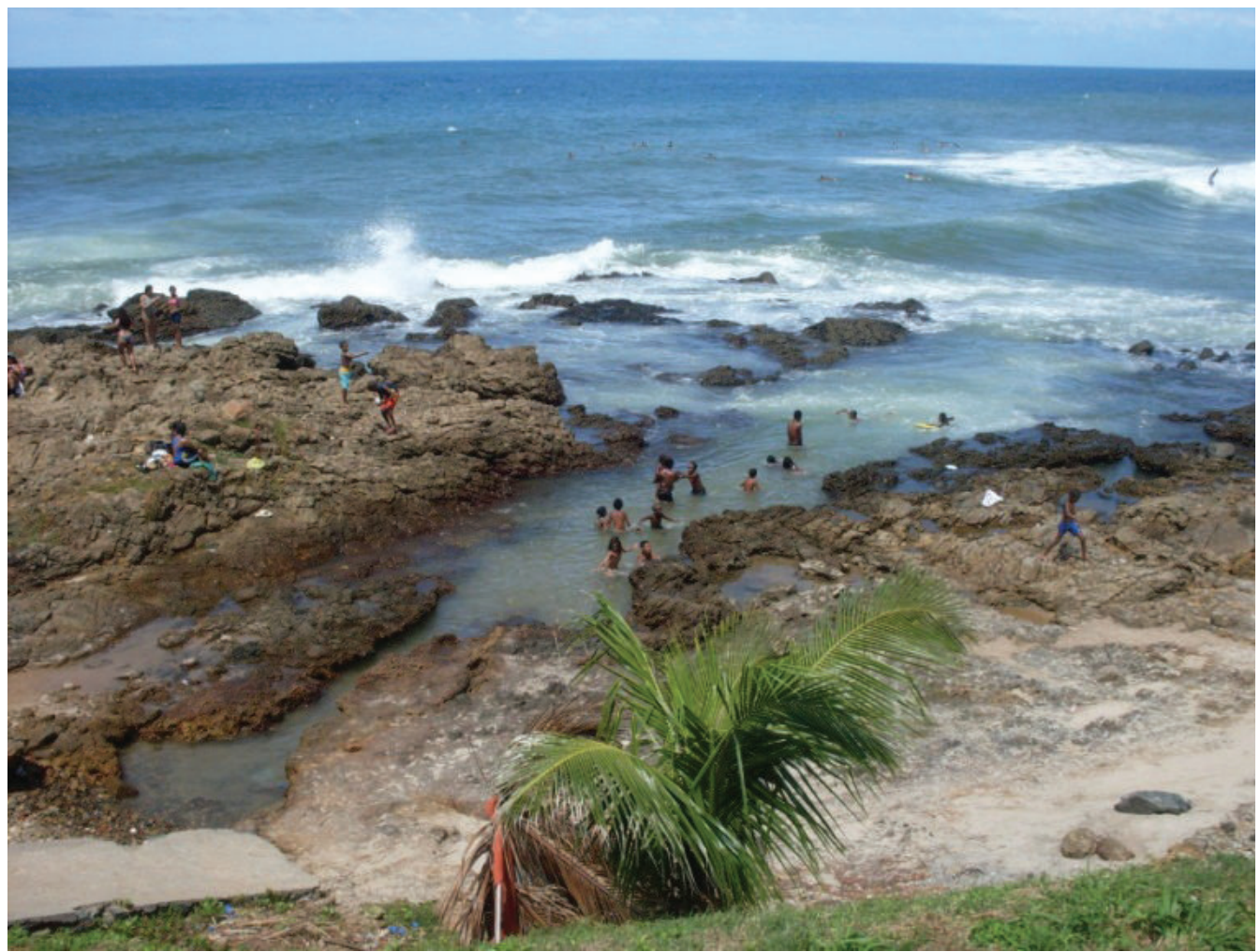

Figura 1 - Crianças banhando-se em "enclaves” de praia. Fonte: acervo do autor.

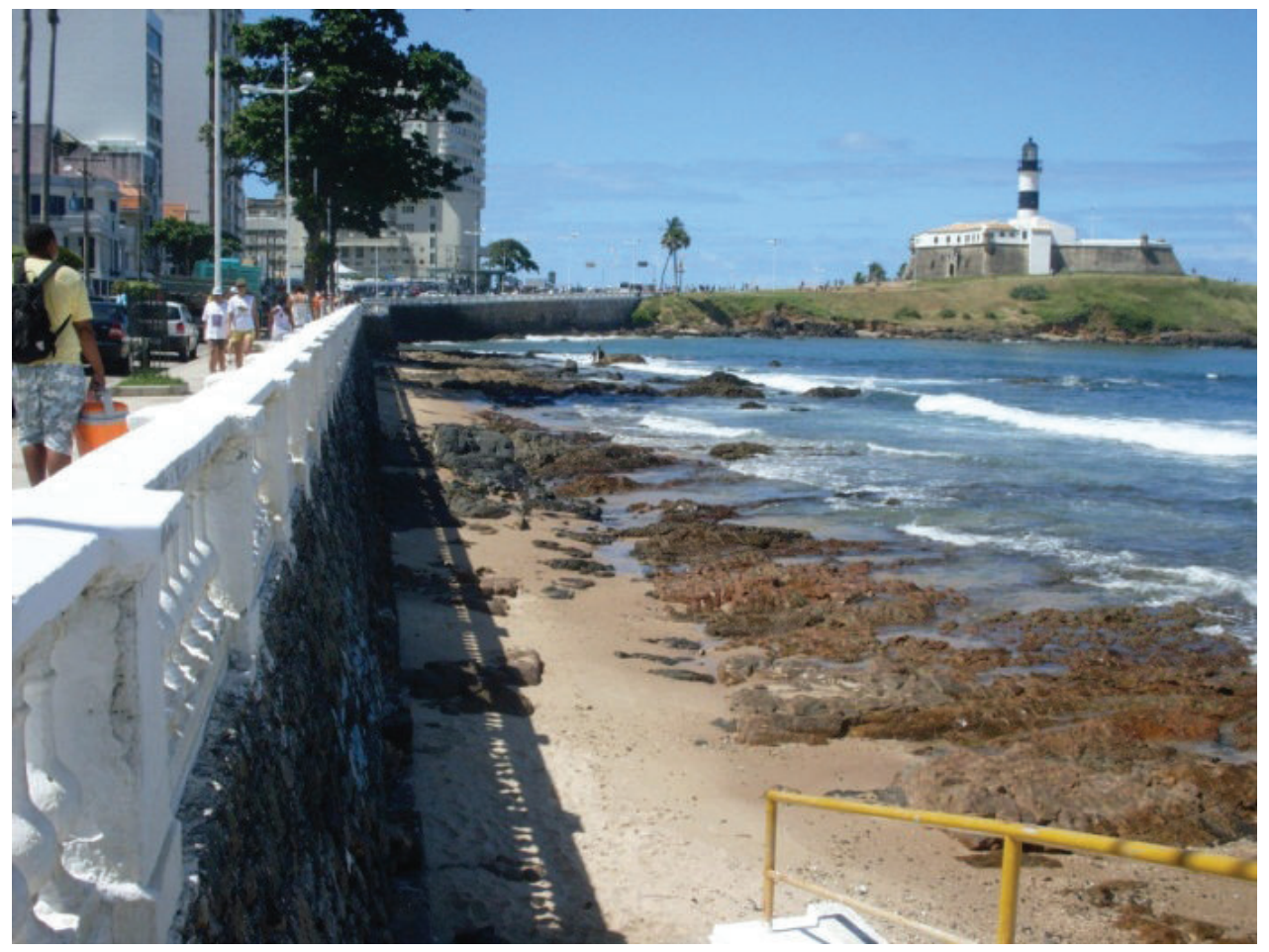

Figura 2 - Pequeno trecho de praia entre alvenaria e afloramentos. Fonte: Acervo do autor 
Me aproximei e me apresentei. O Sr. J. R., vendedor ambulante, 52 anos de idade, brincava com alguns dos seus netos que ele havia levado para passear. As perguntas dirigidas ao Sr. J. R. parecem ter sido esquecidas por ele. "Indisciplinado", o entrevistado enriqueceu, como poucos, a pesquisa.

A praia tem uma coisa boa, uma beleza. Na rua tem aquela agitação toda, mas é só você sentar numa pedra dessa, tomar um banho e você fica tranquilo. O mar tem esse encanto (longa pausa para pensar e olhar as crianças). Se você tem um problema basta você sentar numa pedra, receber um vento que aí vem os pensamentos positivos. Você esquece os problemas. A praia tem esse encanto. A gente precisa procurar um lugar para ter tranquilidade. No mato, por exemplo, você não tem a mesma tranquilidade do mar. Aqui você já conhece, é só não ir para o fundo. No mato não, você não sabe o que tem lá na frente. Aqui é só não ir para o fundo. Aqui é calmo para trazer as crianças, a gente fica a vontade. Há trinta anos era melhor, a gente vem com as crianças e fica preocupado com a vagabundagem. Por aqui tem "rato de praia". Eu não confio muito em levar as crianças para as praias mais cheias. Por isso, a gente vem para essa praia que é mais tranquila. Sr. J. R.

Entusiasmada também estava a Sra. D., 41 anos, recepcionista de pousada, que já havia morado em Salvador e que voltava após oito anos distante da capital baiana. A encontrei numa praia que não se constitui como "enclave" por ser delimitada por grandes afloramentos rochosos, mas por ter sido escondida pela construção, há algumas décadas, de um grande clube ligado à colônia de imigrantes espanhóis.

Praia é para relaxar, é um momento de refletir, então venho aqui, embora as pessoas digam que é violenta. Estava há oito anos fora e voltei há dois meses, e aqui foi o primeiro lugar que tive vontade de visitar. Aqui é familiar, eu estranhei porque está vazio, antes era mais movimentado, tinha aquela coisa bonita de família. Esse pedaço é uma ilhazinha, devia ter mais segurança, as pessoas estão se afastando.

A Sra D. trabalha numa pousada e tem folga de dois dias apenas a cada duas semanas. Nesse pequeno intervalo de tempo, desde o seu retorno a Salvador até a entrevista, a entrevistada sofreu a violência de um assalto no estabelecimento em que trabalha. Daí em diante, ela ficou com muito medo de sair na rua sozinha.

Fui assaltada e só saí porque sou muito atraída por esse lugar. Uma vez fui às praias lá de longe, Stella Maris, aquelas de lá, mas não curti, não tem essa coisa aqui (falava se referindo à areia que apertava com as mãos). Aqui é um lugar de paz, muito familiar, tem gente que vai para a praia para curtir, para beber, mas aqui é um lugar calmo. Está vendo aquele pessoal ali (casal com filho pequeno e um amigo)? Os caras ficam conversando, a mulher passeia com a criança. Está vendo aquele homem (homem de meia idade deitado sobre uma toalha que estendeu em uma pedra)? Ele não sabe o que estou pensando e eu não sei o que ele está pensando, e pronto. É assim. Ele fica na dele lá e eu fico na minha. Aqui a gente pode fazer coisas que não pode fazer em outro lugar. Não é nada demais, sabe? Nada de errado, mas, por exemplo, rolar na areia, ou se você vir um caranguejinho, correr atrás dele sem que ninguém fique te olhando por causa disso, como se você fosse maluca. Aqui não tem nada disso. Se você quer rolar na areia, você rola, se quer comer, come, se quer dormir, dorme. Cada um na sua, sem incomodar os outros.

Ouvindo as palavras da Sra. D. e do Sr. J. R. penso em Bachelard $(1998,2002)$ que nos fala sobre as descrições entusiasmadas dos que falam dos espaços amados.

A descrição entusiasta que dela (a natureza) fazemos é a prova que a olhamos com paixão, com a constante curiosidade do amor (...) Não é porque a montanha é verde ou o mar é azul que nós a amamos, ainda que demos essa razão para nossa atração; é porque algo de nós, de nossas lembranças inconscientes, no mar azul ou na montanha verde, encontra um meio de se reencarnar (BACHELARD, 2002, p. 119-120). 
Essas descrições entusiasmadas, que não se contentam com as palavras, que precisam tocar na areia ou procurar um ponto de fuga para perder o olhar, enquanto relatam um mosaico de imagens que a intenção imaginante evoca, nos põe diante de uma fenomenologia da paisagem.

A sedução das imagens poéticas parece habitar nesse conjunto de sensações que a relação intencional consciência-objeto cria. A tranquilidade buscada pelo ambulante J. R., que ganha a vida nas agitadas ruas da cidade, ou o "ar familiar", o conforto e a proteção, procurados pela recepcionista D., que deixou a família em sua cidade de origem e que sofreu as mazelas da violência urbana, validam essa forma de pensar.

Após analisarmos esses entrevistados, todos nascidos em Salvador e que demonstraram muita intimidade com o nosso litoral, avaliaremos as palavras que disseram outros frequentadores que encontrei na orla marítima da cidade. Estes, porém, visitantes ou moradores recentes da capital baiana.

Foi no morro do Farol da Barra que encontrei J., professor estadunidense, 30 anos, que afirmou morar atualmente com a sua mochila, sem lugar que pudesse nos definir como "sua casa". Eram quase $17 \mathrm{~h}$ e havia uma movimentação intensa de pedestres pelas calçadas. Muitos vendedores ambulantes anunciavam seus produtos aos berros. Senti a temperatura mais amena. O mar tinha um brilho intenso àquela hora.

Assim como procedi com os demais entrevistados, pedi a J. que relatasse um pouco de suas experiências. Com dificuldade de se expressar em nosso idioma ele falou:

O mar é como uma coisa que tem muitas coisas boas, mas com medo também. Tem o medo das correntes, o medo das criaturas. Como menino eu tive experiências maus. A corrente quase me levou uma vez. Isso marcou muito, mas, ao mesmo tempo, tem boas lembranças. O mar é muito especial, tem muito significado espiritual, às vezes. Quando não está conturbando, qualquer pessoa vai entrar num outro estado de mente, outro espírito, tranquilidade total.

Ao ler essas palavras lembro de Bachelard (1998), que nos diz que, no tocante às imagens poéticas, atrair e repelir não resultam em experiências contrárias.

Quando lhe pedi para se concentrar na paisagem e descrever um pouco das suas sensações, J. disse: "Não sei... certa forma de nostalgia. Vendo os meninos na praia eu lembro de eu menino, experimentando o mar de outra maneira. Vejo com muita maravilha".

Outra pessoa de fora da cidade que encontrei, também nas proximidades do morro do Farol da Barra, foi a Sra. L., 34 anos, administradora, que mora em São Paulo. A Sra. L. contou sua experiência com o mar:

Eu conheci o mar aos 10 anos de idade quando fiz uma viagem com os meus pais, mas sempre fui pouco à praia. Só agora, depois de casada, é que passei a frequentar mais o litoral. Agora, se você quer saber se eu gosto de entrar na água, eu não gosto. Eu gosto só de ficar olhando. Eu sinto uma força muito grande na natureza. Quando olho esse mar sem fim, eu sinto uma força muito grande. Primeiro porque é uma criação de Deus, não é? Eu sinto uma coisa muito grande, uma energia, uma coisa muito boa que passa para mim.

Como o Sr. R. S., a Sra. L. também demonstra uma atração pelo mar que perpassa, sobretudo, pela experiência visual. Embora fascinados, a experiência sensitiva da visão parece satisfazer a vontade de ambos estarem próximos às águas do mar.

Ouvindo a minha solicitação para que se concentrasse um pouco mais na paisagem e nas sensações que esta evocava, a senhora L. foi rápida no exercício de adesão à imagem poética.

Se eu olho para o infinito (porção mais distante do mar), eu sinto paz, tranquilidade, satisfação, um bem estar imenso. 
Dentre os que colaboraram com esse exercício, com as experimentações de um método fenomenológico de estudo das paisagens, considero também enriquecedoras as palavras que disse o $\mathrm{Sr}$. G., engenheiro, 26 anos, que nasceu em Goiânia e resolveu há três anos morar em Salvador, onde conseguiu se estabelecer a poucos meses. Foi na orla do bairro de Ondina que o Sr. G. contou sua experiência com o mar:

Eu tinha pouco contato com o mar por morar em Goiânia. Eu conheci o mar aos 8 anos de idade no Espírito Santo e fiquei muito tempo sem ir ao litoral e sem ver o mar. E só recentemente, há uns três anos, visitei Salvador a passeio e gostei muito. Eu vim para cá não tanto pela cidade, mas por causa do mar. Eu não conhecia tanto a cidade quando resolvi morar aqui. Mas pelo fato de ter o lazer, de você saber que tem o mar por perto, a qualquer hora, é muito bom.

Na adesão à imagem poética, o Sr. G. disse fitando a paisagem:

Eu sinto bem estar, calmaria, esqueço os problemas.

Nos relatos desses entrevistados, entrevistados que, repito, foram os que trouxeram as mais ricas contribuições ao esboço metodológico de um estudo fenomenológico da paisagem, ouvi constantemente referências a um outro par dialético caro à teoria de Bachelard: o interior e o exterior. Constatamos essas referências na inclinação para a imensidão diante da imagem poética do mar.

Poderíamos dizer que a imensidão é uma categoria filosófica do devaneio (...). E a contemplação da grandeza determina uma atitude tão especial, um estado de alma tão particular que o devaneio coloca o sonhador fora do mundo próximo, diante de um mundo que traz o signo do infinito (...). A imensidão está ligada a uma espécie de expansão de ser que a vida refreia, que a prudência detêm, mas que retorna na solidão (...). A imensidão é o movimento do homem imóvel (BACHELARD, 1998, p. 189-190).

Referindo-se ao devaneio do infinito, Bachelard discorre sobre um espaço que se estende sem limites e que, contudo, nos põe diante das intimidades - as nossas e as do mundo.

Parece, então, que é por sua imensidão, que os dois espaços - o espaço da intimidade e o espaço do mundo - tornam-se consoantes. Quando a grande solidão do homem se aprofunda, as duas imensidões se tocam, se confundem (...). Como é concreta essa coexistência das coisas num espaço que duplicamos com a consciência de nossa existência! Cada objeto investido de espaço íntimo transforma-se, nesse coexistencialismo, em centro de todo espaço. Para cada objeto, o distante é o presente, o horizonte tem tanta existência quanto o centro (BACHELARD, 1998, p.207).

Podemos apreender nas palavras do filósofo um convite à humanização das coisas do mundo, onde o espaço exterior é investido de espaço íntimo, num processo em que a imaginação participa ativa e simultaneamente "da vida da matéria e da vida das formas" (BACHELARD, 2002, p.32).

Foi gratificante notar os entrevistados subvertendo os pressupostos da entrevista, que buscava inicialmente uma descrição das experiências seguida do exercício do não-saber, oferecendo as surpresas das quais se alimenta um pesquisador.

Dito de outro modo, enquanto buscava tão somente conhecer um pouco mais dos entrevistados através de suas experiências com o mar, estes já davam sinais de adesão à imagem poética.

Os relatos que ouvi dos que colaboraram com a pesquisa me fizeram pensar na solidariedade existente entre a memória e a imaginação responsável pela construção da história, segundo Bachelard (1998).

É nestes termos que Bachelard (1998) nos diz que somos mais poetas do que historiadores e que num determinado momento o filósofo nos pergunta: "O que foi terá sido mesmo? Os fatos tiveram o valor que lhes dá a memória?" (1998, p.72). 
Tingindo os fatos com cores vivas, a imaginação, ao contrário de falsear a história e a realidade, as intensifica. Nessa relação dialética, a imaginação alimenta a memória e lhe perpetua num movimento espiral.

Foram muito mais os tons do que as articulações das palavras que me fizeram pensar assim. Os relatos, ornamentados pelas falas mansas e por olhares distantes, buscavam os espaços íntimos na descrição de experiências passadas.

A intenção imaginante visa à imensidão nas/das imagens poéticas, anunciando um espaço externo, que, se ganha a amplidão do infinito, o faz com base no espaço íntimo no qual se constrói as consciências.

\section{CONSIDERAÇÕES FINAIS}

Quando Sartre (2005) inverteu a ordem idealista, na qual a essência precedia à existência, quando escreveu sobre uma essência completamente diferente daquela dada, concebida a priori, agora resultante da existência, e anunciou "tudo está em ato" (p.16), era da liberdade do homem que falava em última análise.

A análise deveria se deslocar para a relação consciência-objeto, negando uma essência dada, redutora da realidade, sem cair na armadilha de uma consciência que é mero reflexo do mundo.

Pensar a essência posterior à existência significa que somos resultado de um processo de existência e que as coisas (a paisagem e seus significados) não podem ser dadas antecipadamente, sem antes nos relacionarmos (julgarmos) com elas e definirmos seus valores.

Bachelard, ao tratar das imagens poéticas, discorreu sobre a beleza da matéria, e, com isso, nos ofereceu métodos de apreensão das paisagens estudadas, possibilitando a continuidade do esboço de análise da paisagem, iniciado a partir das leituras de Sartre. Tais métodos nos aproximam mais um pouco dos anseios subjetivos e significados doados por um pequeno grupo de entrevistados que ofereceu à pesquisa um rico material.

Depois de ler Bachelard e de testar seus métodos com os entrevistados, fica claro o imenso poder do mar e das paisagens litorâneas em seduzir distintas subjetividades e porque agentes hegemônicos (como, por exemplo, a indústria da construção civil) dispensam tantos esforços a fim de manipular suas imagens.

Porém, são as possibilidades de imaginarmos outras paisagens que representem nossos sonhos de cidade e de vida urbana o que mais anima nessas leituras (as da paisagem e as dos filósofos). Senti muito prazer em notar a espontaneidade de uma infinidade de pessoas que subvertem as "recomendações", o "bom comportamento", as ideias de beleza, modernidade, progresso, e tantas outras que negam o convívio com as diferenças.

Assim penso ser enriquecedor somarmos à análise da produção capitalista da cidade, uma aproximação dos anseios subjetivos da sociedade.

Feito esse primeiro esforço de análise dos anseios subjetivos dos que apreendem as paisagens das nossas idades, ficam algumas questões por responder: até onde (e como) podemos realmente auferir que houve, nos termos propostos pelos teóricos que apoiaram a pesquisa, relação entre essas outras consciências e os objetos analisados? Como podemos afirmar que a intenção imaginante (das outras consciências) lançou-se na direção das imagens poéticas descritas por Bachelard? Em que ponto estariam, essas outras consciências, entre a imagem-lembrança e a imagem-ficção abordadas por Sartre?

Ficam aí sugestões de pesquisa.

\section{REFERÊNCIA BICLIOGRÁFICA}

BACHElARD, G. A Poética do Espaço. São Paulo: Martins Fontes, 1998. 
BACHElarD, G. A Água e os Sonhos: Ensaios sobre a Imaginação da Matéria. São Paulo: Martins Fontes, 2002.

DANTAS, E. W. C. O mar e o marítimo nos trópicos. Revista GEOUSP - Espaço e Tempo. Nº 15. São Paulo, 2004.

DANTAS, E. W. C. Maritimidade nos trópicos: por uma Geografia do litoral. Fortaleza, UFC Edições, 2009. DUARTE, J. F. O que é Realidade? Ed. Brasiliense. São Paulo, 2000.

BACHELARD, G. O que é Beleza? Ed. Brasiliense. São Paulo, 2003.

LEFEBVRE, H. O Direito à Cidade. $4^{\mathrm{a}}$ Edição. São Paulo. Editora Moraes, 2006.

SARTRE, J-P. O Ser e o Nada: ensaio de ontologia fenomenológica. Petrópolis, Ed. Vozes, 2005.

BACHELARD, G. A Imaginação. Porto Alegre, RS. Ed. L\&PM Pocket, 2008.

Trabalho enviado em fevereiro de 2011

Trabalho aceito em abril de 2011 